\title{
Validation of an Area-Wide Extension Program to Estimate the Seasonal Abundance of Adult Citrus Root Weevils with Unbaited Pyramidal Traps ${ }^{1}$
}

\section{S.H. Futch, L.W. Duncan and M. Zekri ${ }^{2}$}

One hundred modified Tedders traps were monitored weekly for 2.5 years in each of seven citrus orchards located throughout Florida. Temporal patterns of the prevalence of adult Diaprepes abbreviatus at each site were compared to determine the feasibility of using insect abundance in sentinel orchards to schedule pest management activities within a region. Weevil abundance in three orchards on Florida's central ridge exhibited no consistent temporal patterns between years or among sites. In three central and eastern flatwoods sites, the abundance of weevils tended to be highest during the spring and early summer, but the variation in this pattern was high between sites and years. The mean abundance of weevils in the flatwoods sites was more than five-fold greater $(\mathrm{P}=0.02)$ than that for sites on the central ridge. These data suggest the need for site-specific monitoring programs to aid in management of D. abbreviatus. Causes of regional variation in the abundance of $D$. abbreviatus merits additional research.
Diaprepes abbreviatus (Diaprepes root weevil) is a serious problem of widespread distribution within the Florida citrus industry infesting approximately 130,000 acres and costing in excess of 70 million dollars annually. Methods to determine the local abundance of the insect are limited and expensive. Many growers do not know when weevils are present in their groves or what the seasonal abundance is for their geographical areas. Without this basic information, control tactics may be improperly implemented. Unbaited pyramidal traps, commonly referred to as "Tedders traps," are sometimes employed to determine the seasonal abundance patterns of the weevils (Duncan et al., 2001). After emergence from the soil, the adults are attracted to any nonreflective silhouette (a citrus tree trunk or another structure placed in the grove) that simulates a tree trunk. Grower acceptance of the use of "Tedders traps" has been relatively poor due to the time and cost of regularly servicing and monitoring the traps. However, data from various studies have shown regional similarity in adult emergence and abundance

1. This document is HS994, one of a series of the Horticultural Sciences Department, Florida Cooperative Extension Service, Institute of Food and Agricultural Sciences, University of Florida. Published February 2005. This research was supported by the Florida Agricultural Experiment Station, and approved for publication as Journal Series No. N-02573. This project is supported by the USDA Diaprepes Grant \#727384112. Visit the EDIS Web site at http://edis.ifas.ufl.edu.

2. S.H. Futch, extension agent IV, Horticultural Sciences Department, Citrus REC, Lake Alfred, Florida, L.W. Duncan, professor, Entomology and Nematology Department, Citrus REC, Lake Alfred, Florida and Mongi Zekri, extension agent III, Horticultural Sciences Department, Hendry County Extension Office, LaBelle, Florida; Cooperative Extension Service, Institute of Food and Agricultural Sciences, University of Florida, Gainesville, 32611.

The Institute of Food and Agricultural Sciences (IFAS) is an Equal Opportunity Institution authorized to provide research, educational information and other services only to individuals and institutions that function with non-discrimination with respect to race, creed, color, religion, age, disability, sex, sexual orientation, marital status, national origin, political opinions or affiliations. U.S. Department of Agriculture, Cooperative Extension Service, University of Florida, IFAS, Florida A. \& M. University Cooperative Extension Program, and Boards of County Commissioners Cooperating. Larry Arrington, Dean 
on a seasonal basis. The objective of this study was to determine whether an area-wide scouting program using Tedders traps to estimate the emergence and seasonal abundance of adults can assist growers in instituting control methods for this weevil.

\section{Materials and Methods}

A two-and-one-half-year survey was implemented to estimate the seasonal abundance of adult Diaprepes root weevils using 100 unbaited pyramidal traps per location in six major regions in Florida. Three study sites were located on the Florida central ridge in Lake and Polk Counties, and four sites were in flatwoods conditions in DeSoto, Hendry, Indian River and Dade Counties. Florida's central ridge is characterized by deep, well-drained sandy soils. Depth to groundwater is much shallower in the coastal and central "flatwoods" regions, where trees are generally grown on beds to increase the soil volume suitable for root growth. Soil texture and drainage characteristics vary greatly among flatwoods sites. Initially, all sites were commercially producing citrus groves, known to be infested with Diaprepes for four to six years and were irrigated with low-volume microsprinkler irrigation systems. The Indian River and Dade County sites were changed to other locations after the first year of the study. The original Indian River site was replaced with another citrus grove which was under the same management whereas the Dade County site was relocated to an ornamental tree nursery. Site descriptions, sample areas and trap spacings are given in Table 1.

Data was collected by grower cooperators who reported the number of weevils captured in each trap during each previous seven-day period. Graphical data summaries were posted weekly at www.lal.ufl.edu/diaprepes/diaprepesemergence.htm and were freely available to growers who were informed about the survey through extension citrus newsletters, magazines and meetings.

Soil samples from each site were processed to determine the particle size distribution. Oven-dried samples $(100 \mathrm{~g})$ were dispersed in a dilute alkaline solution of sodium metaphosphate on a mechanical shaker overnight and rinsed thoroughly on a 0.053 mm opening sieve to remove silt and clay particles. Soil remaining on the sieve was dried, mechanically shaken on a nested series of sieves $(0.053,0.106$, 0.25, 0.5, $1.0 \mathrm{~mm}$; Rototap RX-29, W.S. Tyler, Mentor, $\mathrm{OH}$ ), and fractions retained by each were weighed. Relationships between weevil abundance and soil particle size classes at each site were investigated by graphical examination and calculation of linear correlation coefficients.

\section{Results and Discussion}

Although locations were known to have been infested with Diaprepes for at least four to six years, the emergence patterns and average weevils collected per trap varied greatly between the study sites. Previous reports have indicated that although adult emergence and abundance can vary throughout the year, the primary emergence period is normally in April to mid-July and/or late-August to mid-October (McCoy et al., 2004). Data from this study agrees with year-round presence; however, the patterns often differed from discreet spring and fall peaks of abundance. Following is a brief discussion of seasonal abundance patterns for each of the three well-drained sites in of Lake and Polk locations (Figure 1).

\section{Lake County}

Weevil abundance increased from early May 2001 until mid July when numbers peaked following a major rain event of greater than 6 inches in a one-week period. This spike was somewhat like an event at the DeSoto location below. Nigg et al., (2003) also reported that adult weevil emergence in a central Florida citrus orchard was initiated following the onset of the summer rains in July, following an unusually dry spring and early summer. After July, the weevil abundance remained relatively low $(<0.1$ weevils per trap per week) for the remainder of the survey year. Abundance during 2002 remained low the entire year at less than 0.1 weevils per trap per week until the fall when weevil capture increased somewhat from November until February 2003. Thereafter, weevil abundance remained low until the survey terminated in October. 


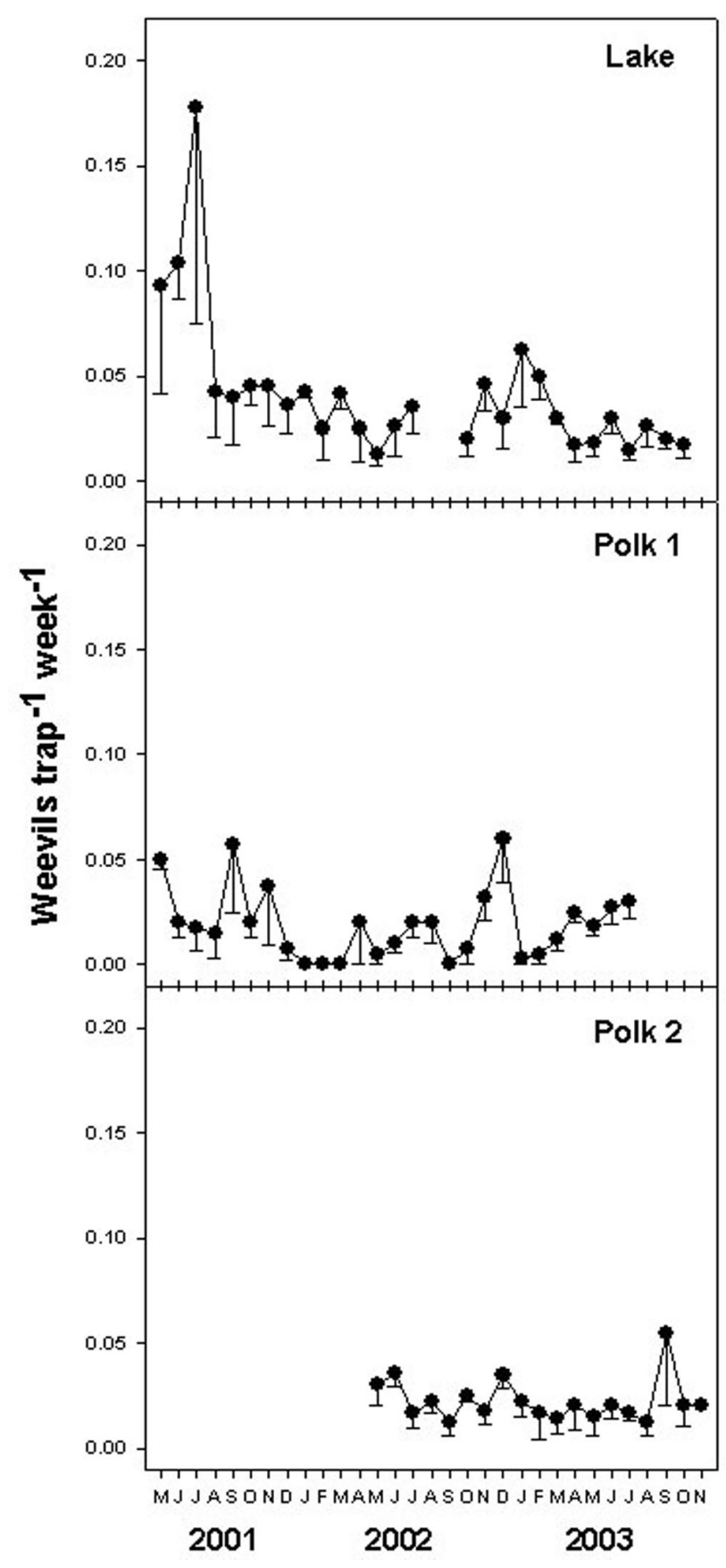

Figure 1. Numbers of Diaprepes abbreviatus collected per trap each week during 31 months in three citrus orchards on the central ridge of Florida. Weekly data for each month were averaged to better illustrate seasonal patterns. Error bars are standard errors of the mean.

\section{Polk County I}

This location had the lowest weevil population ( $<0.1$ weevils per trap) of any of the six survey sites. Weevil populations declined from May 2001 until September when they increased slightly. Very few weevils were captured early in 2002, until April. As in Lake County, weevil abundance increased in autumn of 2002 and highest numbers occurred in December. The number of weevils declined sharply in January 2003 and increased gradually thereafter. This grove was known to be infested with weevils for more than six years and is in a location where many other groves are infested with weevils.

\section{Polk County 2}

Trapping at the second Polk County site occurred from May 2002 until November 2003, and weevil abundance was low throughout the survey. Populations were slightly higher in May-June and December 2002 and may have increased briefly in September 2003.

The less well-drained sites are typical of the flatwoods and east coast areas include DeSoto, Hendry and Indian River (Figure 2).

\section{DeSoto County}

The first major peak in abundance occurred from May through July 2001 followed by a steady decline in numbers for the remainder of the year. An interesting event occurred in early July 2001 when heavy rains triggered a major emergence totaling 2.14 weevils per trap for the weekly period (not shown). These heavy rains (12 inches in two weeks) cause localized short term flooding within the grove for several days. This event indicates that a large number of mature weevils can be in the soil and will emerge when forced or encouraged to emerge based upon environmental or other factors (Nigg et al., 2003). Weevil abundance remained relatively low $(<0.10$ weevils per trap) until May 2002. After July the numbers of weevils declined for the remainder of the year. Abundance again increased in March of 2003, with peak emergence in April then declining somewhat into the summer.

\section{Hendry County}

This location had the highest average weevil levels among the seven sites. Weevil abundance was high in April 2001 at the beginning of the study ( $>0.5$ weevils per trap) and decreased steadily for the remainder of 2001. In 2002, abundance began to 


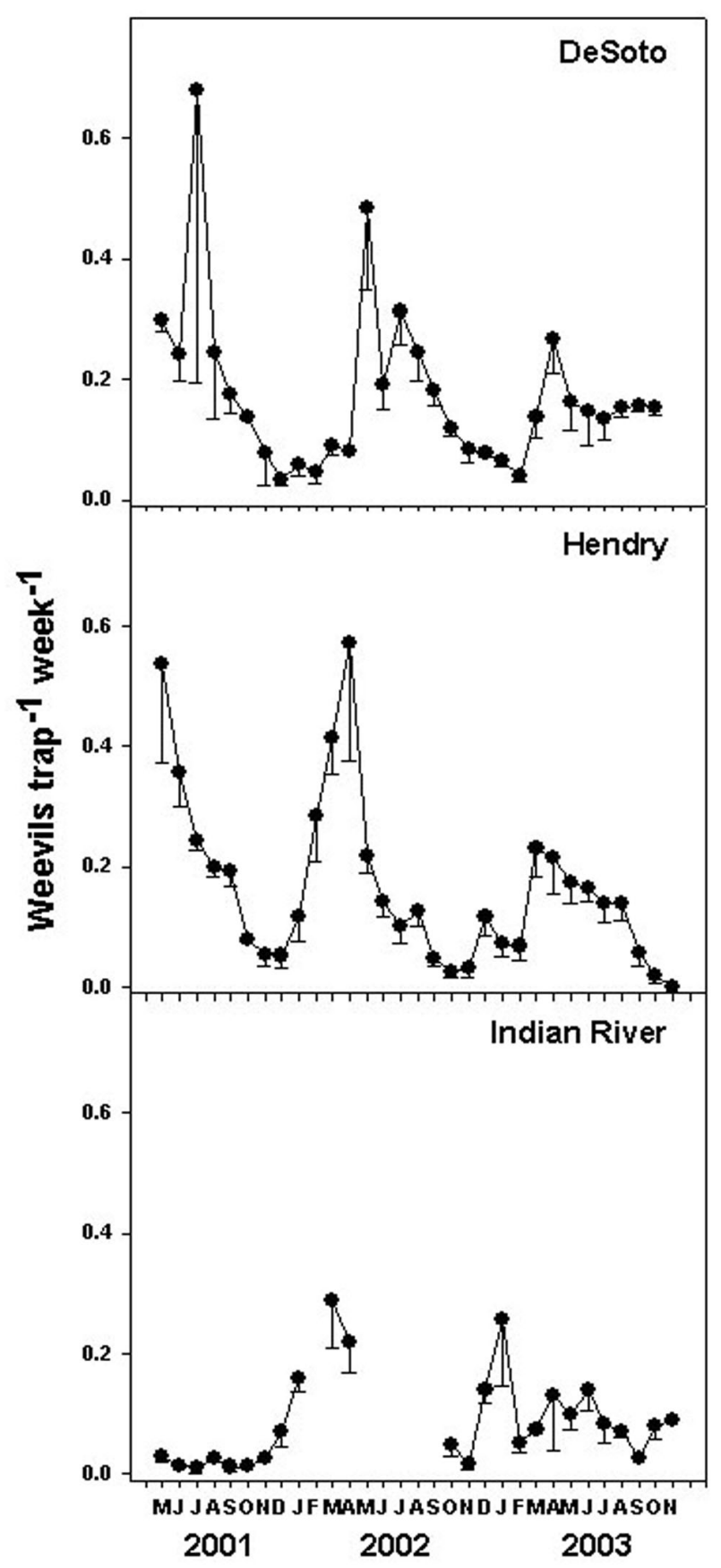

Figure 2. Numbers of Diaprepes abbreviatus collected per trap each week during 31 months in three citrus orchards in flatwoods regions of Florida. Weekly data for each month were averaged to better illustrate seasonal patterns. Error bars are standard errors of the mean.

increase in January, with peak recovery in March and April, and then declined for the remainder of the year. In 2003, weevil abundance followed a similar pattern, peaking in March and gradually declining thereafter.

\section{Indian River County}

Emergence at this location was extremely low $(<0.04$ weevils per trap) from the beginning of the survey in early April 2001 until December. This pattern did not follow the trends of the other flatwoods locations. Beginning in mid December 2001, abundance began to increase until mid April and then began to decline in late April 2002, when this grapefruit grove was removed due to small fruit size and low fruit prices. The grove was in good horticultural conditions at the time of tree removal. The site was replaced with a grove in the same general area in October 2002. At the new site, abundance increased in December 2002, with peak emergence in January 2003, then declined until April when populations levels increased somewhat until June.

\section{Dade County}

The abundance pattern varied from 0 to 0.15 weevils per trap per week but lacked any major or strong emergence patterns during 2001 (Figure 3). Weevils were trapped throughout the year at low levels. The location was receiving limited care (irrigation and nutritional inputs), which could have limited the flushing cycle of the trees thereby reducing or limiting weevil numbers. Peak abundance occurred in June and July 2002. This site was replaced in September 2002 with an ornamental site that supported higher numbers of weevils. Emergence peaked at the ornamental site in January and again in August 2003.

\section{Conclusions}

The average weekly abundance of weevils was more than five-fold greater $(\mathrm{P}=0.02)$ in the flatwoods sites (DeSoto, Hendry, Indian River Counties) than that in sites on the central ridge (Lake and Polk Counties) (Figure 4). Adult weevil numbers were highest at the DeSoto and Hendry, followed by Indian River locations. This regional trend for weevil population pressure is consistent with previous reports, although the causes of variation in weevil numbers between sites is unknown (Adair, 1994; Stansly et al., 1997; Duncan et al., 2001). Duncan et al. (2003) reported greater natural control of $D$. abbreviatus by entomopathogenic nematodes in an 


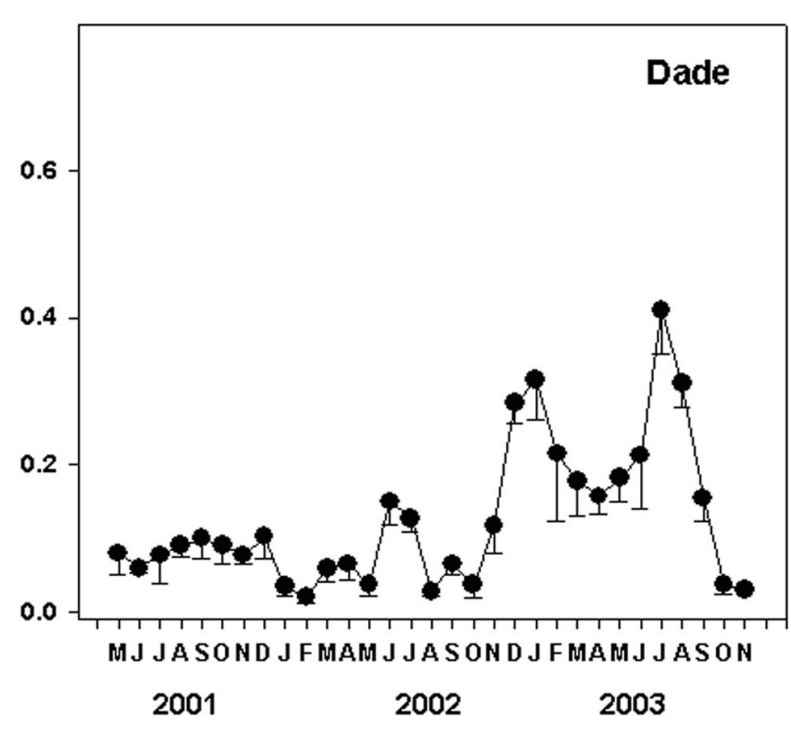

Figure 3. Numbers of Diaprepes abbreviatus collected per trap each week during 31 months in a citrus orchard in Dade County, Florida. Weekly data for each month were averaged to better illustrate seasonal patterns. Error bars are standard errors of the mean.

orchard on coarse sandy soil on the ridge compared to one on sandy clay loam in the flatwoods. However, we detected no relationships when weevil abundance was plotted against the proportions of any of the sand particle sizes and linear correlation coefficients between abundance and soil particle sizes were not significant $(\mathrm{P}>0.10)$.

When data were pooled within regions, weevil abundance was highest in the spring to mid-summer (March - July) of each year in the flatwoods, which is consistent with other reports (Adair, 1994; Duncan et al., 2001). Seasonal abundance was not apparent for the pooled data from the ridge sites, although abundance has been reported to increase consistently in the spring and occasionally in the autumn from individual sites on the ridge (Duncan et al., 2001).

While population trends within each geographical region should be somewhat similar, the temporal abundance of weevils varied significantly with location. Weevil pressure tended to be higher in flatwoods orchards compared to those on the central ridge.

This website provided an easily accessible source of timely information of weevil abundance trends in selected sites. Knowledge of these

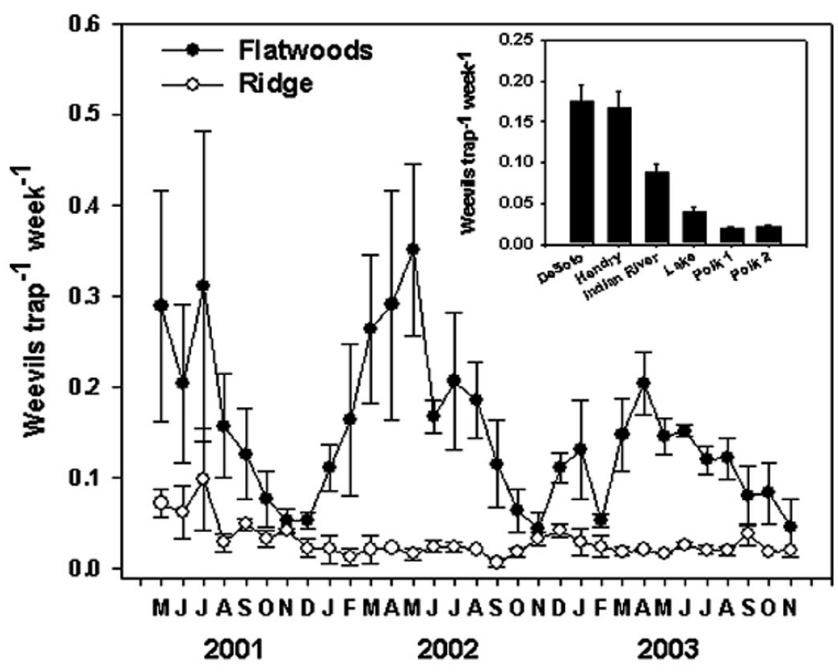

Figure 4. Average numbers of Diaprepes abbreviatus collected per trap each week during 31 months in three citrus orchards in flatwoods regions and three orchards on the central ridge of Florida. Weekly data for each month were averaged to better illustrate seasonal patterns. Inset shows the tree-year average for each grove used in the study. Error bars are standard errors of the mean.

population patterns may help growers anticipate seasonal weevil population growth in order to time management strategies more effectively; however, management decisions should be based on supplemental observations regarding site-specific population levels. Data for the entire study is available on the web at: www.lal.ufl.edu/diaprepes/diaprepesemergence.htm .

\section{References}

Adair, R. C. 1994. A four-year field trial of entomopathogenic nematodes for control of Diaprepes abbreviatus in flatwoods citrus groves. Proc. Florida State Hort. Soc. 107, 63-68.

Duncan, L. W., C. W. McCoy, P. H. Stansly, J. H. Graham and R. F. Mizell. 2001. Estimating the relative abundance of citrus root weevils with modified Tedders traps. Environ. Entomol. 30, 939-946.

Duncan, L. W., J. H. Graham, D. C. Dunn, J. Zellers, C.W. McCoy, and K. Nguyen. 2003. Incidence of Endemic Entomopathogenic Nematodes Following Application of Steinernema riobrave for 
Control of Diaprepes abbreviatus. J. Nematol. 35:

178-186.

McCoy, C. W., S. H. Futch, J. H. Graham, L. W. Duncan and H. N. Nigg. 2004. Citrus Root Weevils. In 2004 Florida Citrus Pest Management Guide, (L. W. Timmer, ed.), SP-43, University of Florida, Florida Cooperative Extension Service, Institute of Food and Agricultural Sciences, Gainesville.

Nigg, H. N., S. E. Simpson, R. J. Stuart, L. W. Duncan, C. W. McCoy and F. G. Gmitter Jr. 2003. Abundance of Diaprepes abbreviatus (L.) (Coleoptera: Curculionidae) Neonates Falling to the Soil Under Tree Canopies in Florida Citrus Groves. Horticultural Entomology. 96, 3, 835-843.

Stansly, P. A., R. F. Mizell and C. W. McCoy. 1997. Monitoring Diaprepes abbreviatus with Tedder's traps in southwest Florida citrus. Proc. Florida State Hort. Soc. 110, 22-26. 
Archival copy: for current recommendations see http://edis.ifas.ufl.edu or your local extension office.

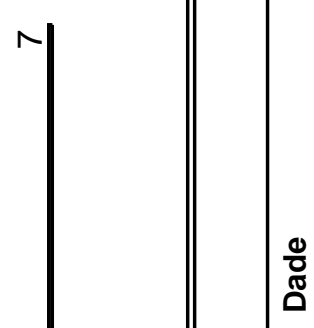

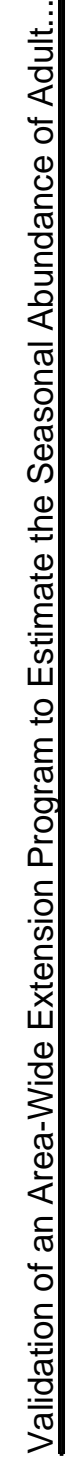

ํㅗำ

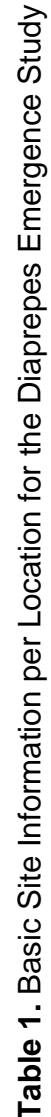

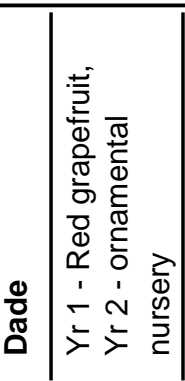

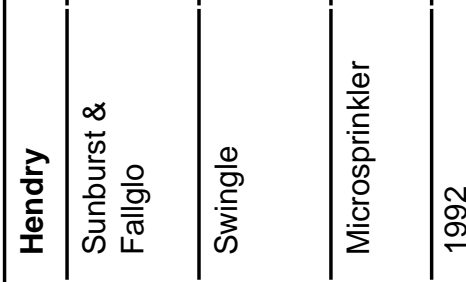
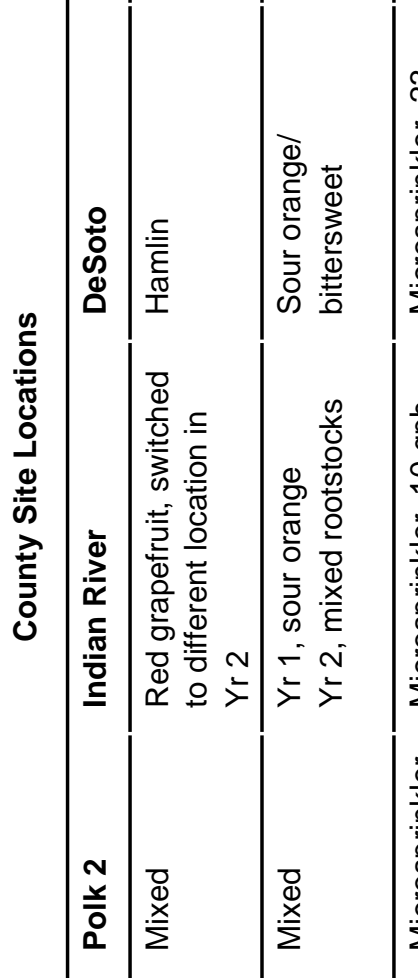

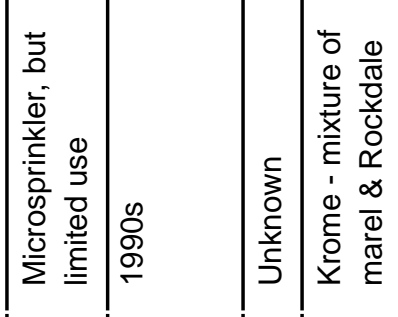

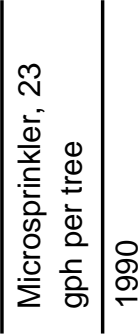

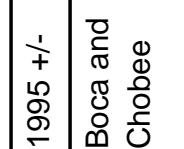

(2)

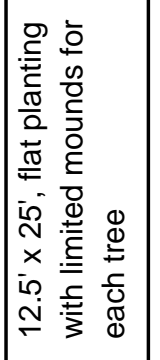

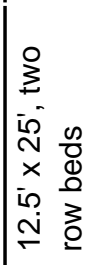

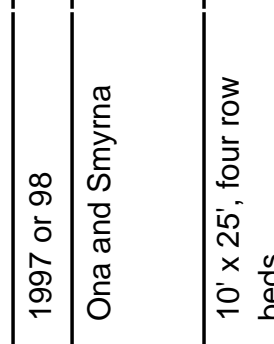
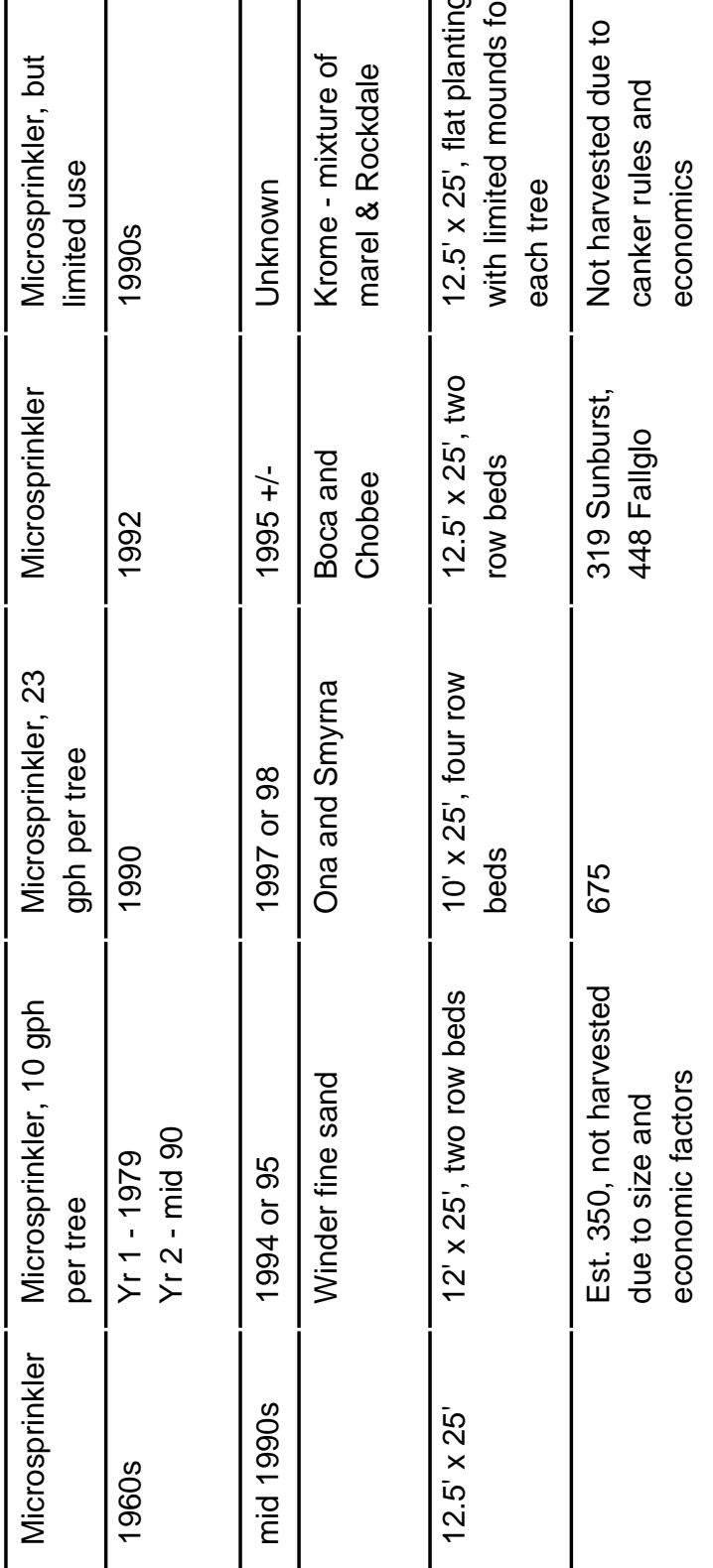

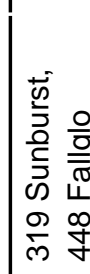
.
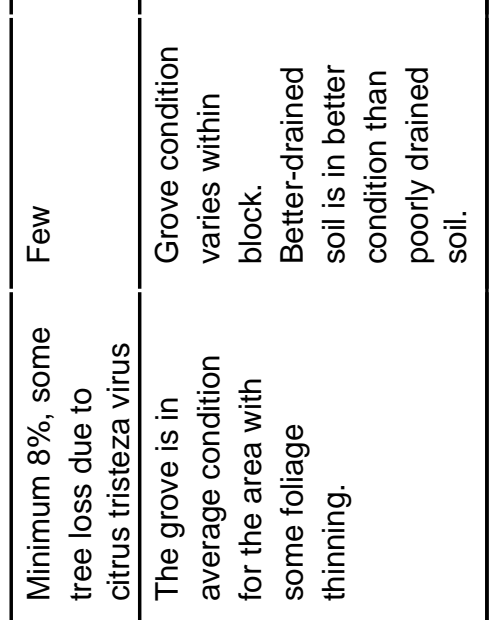

\begin{tabular}{|c|}
\hline 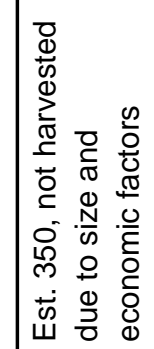 \\
\hline
\end{tabular}
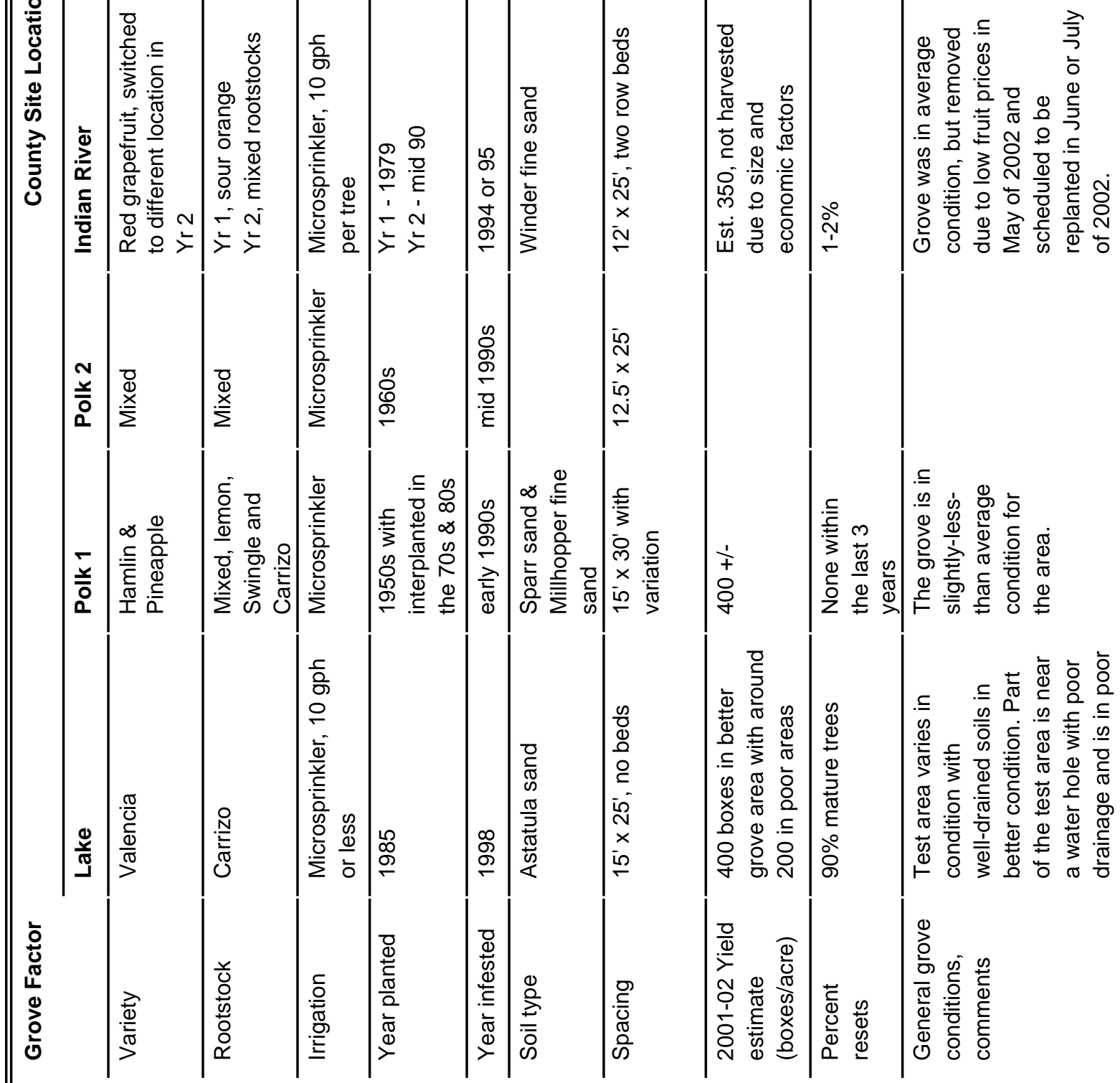

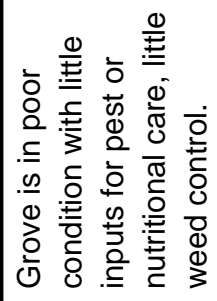
Ф

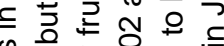
更

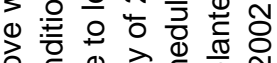

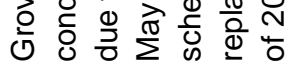

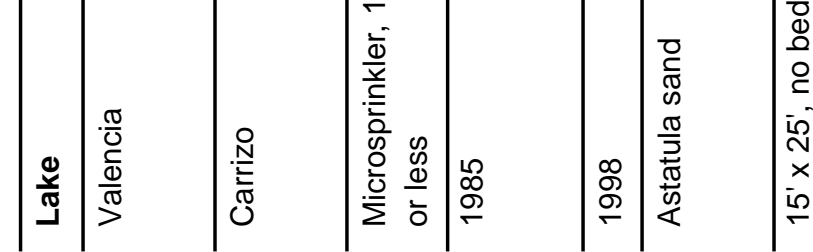

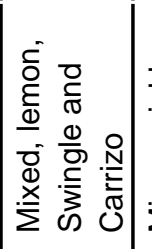

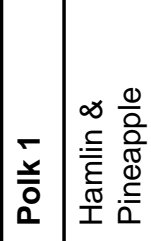
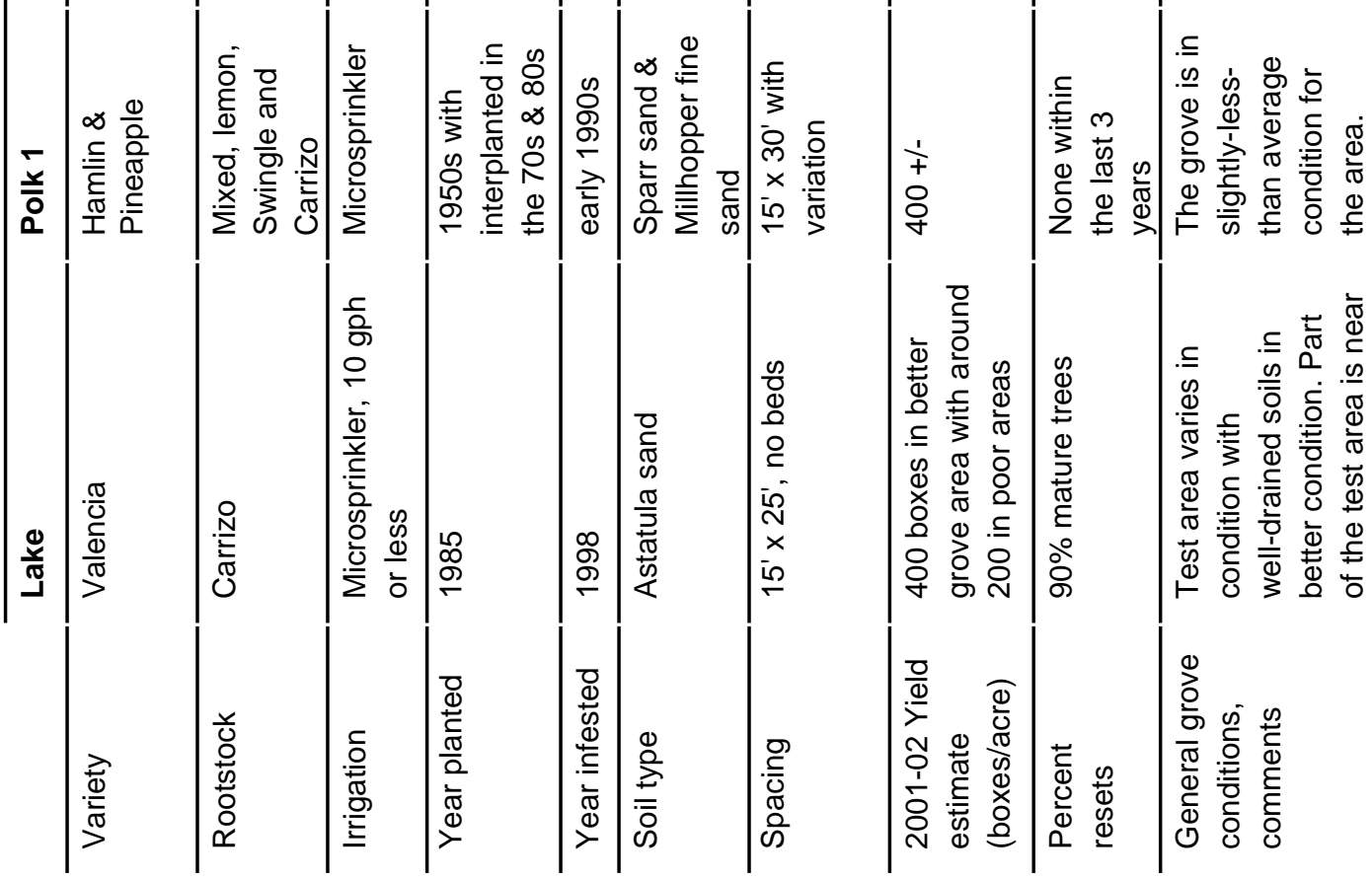